International Journal of Instruction

e-ISSN: 1308-1470 • www.e-iji.net

Article submission code:

20200706030634

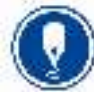

Received: 06/07/2020

Revision: 14/01/202
July $2021 \bullet$ Vol.14, No.3

p-ISSN: 1694-609X

pp. 685-704

Accepted: 08/02/2021

OnlineFirst: 10/06/2021

\title{
The Effect of Blended Project-Based Learning with Stem Approach to Spatial Thinking Ability and Geographic Skill
}

\section{Alfyananda Kurnia Putra}

Universitas Negeri Malang, Indonesia, alfyananda.fis@um.ac.id

\section{Sumarmi}

Universitas Negeri Malang, Indonesia, sumarmi.fis@um.ac.id

\section{Ifan Deffinika}

Universitas Negeri Malang, Indonesia, ifan.deffinika.fis@um.ac.id

\section{Muhammad Naufal Islam}

Universitas Negeri Malang, Indonesia, mnaufalislam.1707216@students.um.ac.id

The purpose of this study was to determine the effect of Blended Project-Based Learning (BPjBL) with the STEM approach to spatial thinking skill and geography skill and student's attitudes in implementing the learning. The research design used quasi-experimental research and independent t-test and paired t-test as data analysis. The selection of population was used random sampling techniques to second-year students of National Senior High School 1. Population in this study was the social science class at SMA Negeri 1 Kepanjen Malang, Indonesia. The students were divided into two groups, experimental group from social class 1, which used the BPjBL and control group from social class 3, which used the conventional method. The results showed that there was a significant influence of BPjBL with STEM approach to spatial thinking skill and geography skill. The changes in students' attitudes also shown significantly towards spatial thinking skill and geography skill. This research proved that the application of project-based learning could develop spatial thinking skill and geography skill as 21 st-century learning objectives.

Keywords: blended project-based, stem, spatial thinking skill, geography skill, learning

\section{INTRODUCTION}

The development of science and technology in 21 st-century education has led to a paradigm shift in learning. The quality of learning in this era was primarily determined by the integration of technology, information and communication (R. J. Chen, 2010; Claro et al., 2012). Technology can help strengthen student learning processes for the better (Mishra \& Koehler, 2006). The teachers are not only in charge of the learning process, but is able to build effective and collaborative relationships with digital

Citation: Putra, A. K., Sumarmi., Deffinika, I., \& Islam, M. N. (2021). The effect of blended projectbased learning with stem approach to spatial thinking ability and geographic skill. International Journal of Instruction, 14(3), 685-704. https://doi.org/10.29333/iji.2021.14340a 
technology-based students and school communities, while continuing to reflect and improve learning practices on an ongoing basis (Clark, 2010; Harris et al., 2009; Laurillard, 2009).

The success of technology integration in learning can be seen from the teacher's competence to design learning material. The application of learning models in the classroom is the primary key to achieve learning objectives (Sun et al., 2018). Relevant learning models are Blended Learning (BL) and Project-Based Learning ( $\mathrm{PjBL}$ ) learning models.

Blended Learning presents flexibility in digital learning without space and time restrictions. It can be achieved by creating a synchronous and asynchronous learning atmosphere so that students have optimal time to learn (Owston et al., 2013; Zydney et al., 2020). Technology has provided the effectiveness and efficiency of learning to improve knowledge and performance (Laurillard, 2007; Oludare Jethro et al., 2012). The power of technology results in collaborative professional learning involving reflection, production, synthesis and analysis (Aubusson et al., 2009).

Another learning model that widely used by geography teachers is Project-Based Learning. This model can help students to be actively involved in the learning process (Vesikivi et al., 2020), build an inquiry attitude by working collaboratively on a projectbased approach with a comprehensive approach (Bell, 2010). Project-Based Learning used an innovative approach that teaches many important strategies for success in the 21st century (Bell, 2010). This learning was integrated with technology to motivate students to solve challenging assignments in problem-solving and high order thinking skill (English \& Kitsantas, 2013; Grant, 2011). Project-Based Learning facilitates students who have difficulty in transferring knowledge from one area of science to another.

The combination of Blended Learning and Project-Based Learning into Blended Project-Based Learning (BPjBL) is something new in the learning process. It facilitates students to solve project-based problems through e-learning. The learning model emphasizes the intensity aspects of time, facilitated by Blended Learning with the concept of no limits, both space and time so that it can support the active learning process.

However, there are also problems with implementing Blended Project-Based Learning in geography class. When applying this learning model, some teachers use online learning only as a complement to traditional learning and fail to change the teaching process in traditional classes (Cui \& Zheng, 2018). Also, students were lack of feedback and guidance because of the lack of collaboration and effective supervision management. Problems in implementing Blended Project-Based Learning are focused on the preparation of imperfect instructional learning.

Geography is one of the subjects learned for high schools in Indonesia. Geography provides opportunities for students to develop their character and skill in global competition and the industrial revolution of 4.0 (Aliman et al., 2019). Changes in the characteristics of students in the 21 st century require teachers to deal with new 
pedagogical competencies (Anđelković et al., 2018; Lay et al., 2013). It involves learning about population dynamics in development planning as part of the geography course. The complexity requires the use of appropriate, efficient and effective learning models.

New pedagogical development can help teachers to think globally through the presentation of the local problems by using actual data that is assisted by information and communication technology (Karakoyun \& Lindberg, 2020). One of the essential abilities to learn geography for students is to achieve is spatial thinking skill and geography skill (de Miguel González \& de Lázaro Torres, 2018; Schade et al., 2013).

The origination of this study reveals the influence of the BPjBL model with the STEM approach to explore the spatial thinking skill and geography skill of high school students. Through STEM students can have skill such as problem-solving, creativity and critical analysis (Erdogan et al., 2016; Wilhelm, 2014) and spatial ability (Taylor \& Hutton, 2013; Uttal \& Cohen, 2012). This application can improve students' abilities and skill in learning Geography. Students who have spatial thinking ability can think critically to interpret information and make decisions in the future (R. S. Bednarz, 2006; Karanikolas, 2009). Spatial thinking can critically interpret information and make decisions based on the spatial concept (Duke \& Kerski, 2010).

Meanwhile, geography skill is the basic skill that students from geography major must study. These skills are important to make decisions based on geography (spatial) by analysing information to make conclusions based on the spatial concept (Kneale, 2019; Ridha et al., 2019). Understanding various physical and non-physical objects, and their interactions become necessary skill in geography (Thomas-Brown, 2011). This skill requires geospatial tools and technology that represents the geography, such as satellite imagery, digital maps, Web Geography Information System and others. In general, combining geography with the Blended Project-Based Learning model with the STEM approach presented in LMS facilities is still not widely done.

Learning geography using the STEM approach can support the presentation of digital learning to improve interests and motivate students. Based on the results of the study, some students are not interested to learn using traditional methods (Mitchell \& Forer, 2010; Sulisworo \& Toifur, 2016). Therefore, the use of technology can transform weaknesses into strengths so that learning objectives could be achieved (Laurillard, 2007), which are meaningful, motivating, inspirational and interactive (Carver et al., 2004).

STEM is a new approach in the learning process. The STEM approach emphasizes the combination of four aspects, i.e. science, technology, engineering, and mathematics, in the learning process (Anisimova et al., 2020; Daher \& Shahbari, 2020). Learning with the STEM approach can bring changes to the learning process to be more effective and efficient (Cheng \& Tsai, 2013).

The STEM approach can improve students' cognitive, affective, and psychomotor abilities. Integrating four aspects of STEM can help students improve their ability to solve life problems (Anggraini \& Huzaifah, 2017). STEM is flexible and easily 
integrated with other learning models to achieve learning objectives. Blended ProjectBased Learning is very effective to be used to improve attitudes towards students in the learning process.

Student attitude is closely related to student performance in the learning process. Student performance is influenced by motivation (Chang et al., 2014; Law et al., 2019) and student interests (Larson \& Sung, 2009). Both of these are important points to build an optimal learning process from both teachers and students (Krapp, 1999). The STEM approach can facilitate student attitudes in the learning process (Tseng et al., 2013).

STEM is an integrated approach that can improve the use of the Blended Project-Based Learning model. The integration of STEM in Blended Project-Based Learning models creates a conducive learning atmosphere and environment. It is because students not only learn the technology but also can integrate the technology with appropriate instructional steps.

\section{METHOD}

\section{Preliminaries}

Research Problems and Questions

Blended Project-Based Learning can be integrated with certain learning materials in the learning process. Geography, as a science, can use this model to improve the quality of learning. Geography with learning materials that is broad and deep requires a particular approach in the learning process. In this study, researchers answered two research questions:

RQ 1: The effect of using the Blended Project-Based Learning model using the STEM approach to spatial thinking skill and Geography skill.

RQ 2: The students' attitudes towards Geography learning with the Blended ProjectBased Learning model in groups experiment.

\section{Research Hypothesis}

The hypothesis in this study are:

RQ 1:

$\mathrm{H}^{0}$ : There are no significant differences between the experimental and control groups

$\mathrm{H}^{1}$ : There are significant differences between the experimental and control groups

RQ 2:

$\mathrm{H}^{0}$ : There are no significant differences in students' attitudes in the experimental group

$\mathrm{H}^{1}$ : There are significant differences in students' attitudes in the experimental group

This study used a quasi-experimental study because participants are selected based on specific criteria (Klein et al., 2006). The study design used pre-test and post-test for two assessment groups. The research design can be seen in the following table 1 . 
Table 1

Research design

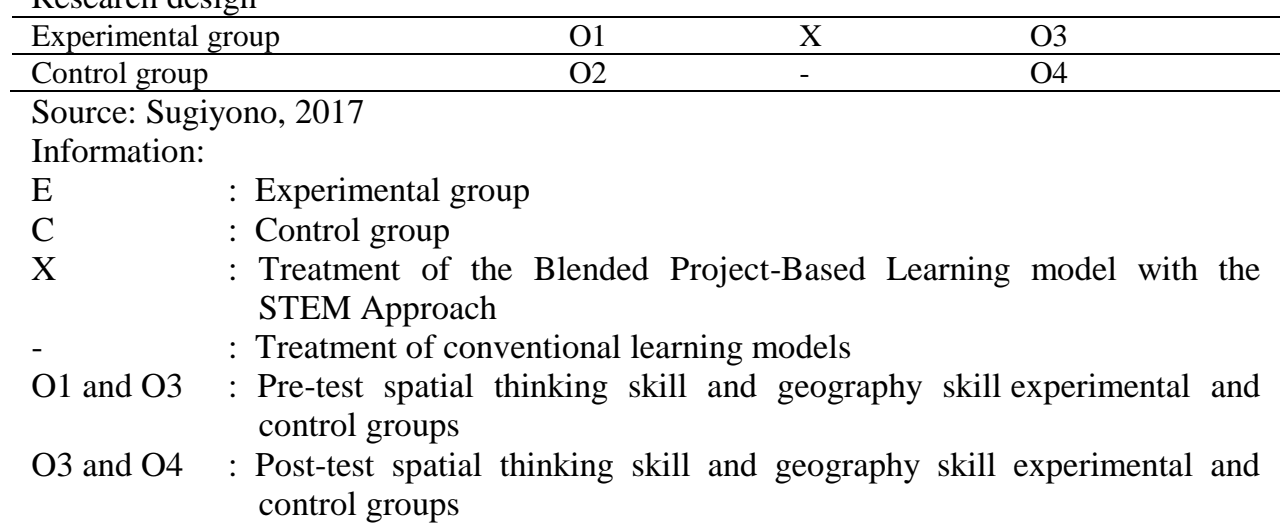

\section{Research subject}

This research was conducted in Kepanjen, Malang, Indonesia. The subject of research were second-year students of National High School 1 in the academic year of 2019/2020. Geography course taught was Population Dynamics in Indonesian Development Planning. The learning material was presented in the second semester based on the 2013 curriculum (revised edition) in Indonesia. The scope of lessons includes population projection, population and labour mobility, population quality, demographic dividend, and population data analysis.

The selection of the experimental group and the control group was used random sampling technique. Research subjects were second-year students from the Social Science class. The experiment group was the students from social science $1(n=36)$ given the treatment of the Blended Project-Based Learning model with STEM approach while the control group was the students from social science $3(n=35)$ given the treatment of conventional learning.

\section{Research Implementation Procedure}

Conducting research using Blended Project-Based Learning in the learning process as follows;

a. Seeking of information: Students explore information from various online and offline learning sources with the principle of relevance and reliability of population dynamics content. Researcher, also as a teacher, provide stimulus questions about geography, making it easier for students to independently choose the sub-topics of population dynamics that they want to explore. Researchers also share the stimulus using students google classroom accounts related to information and learning activities. Searching for the literature, solving problems based on data and conducting inferences, predictions, and concluding are the processes of scientific literacy (Gormally et al., 2012). The learning experience that gained was being able to explore the resources and had reliability with creativity, think critically and foster confidence to choose learning 
resources. The process of finding a variety of information has been planned through various schedules in the digital classroom provided.

b. Acquitting of information: students and teacher conducted online discussions using Google Meet about information obtained during exploration. Students communicate and interpret ideas in worksheets and send it to google classroom. Students downloaded population data presented in WebGIS owned by the Ministry of Internal Affairs, also from the data of social and population by the Central Bureau of Statistics of Indonesia. The data were used to make project calculations of population projections that visualized as maps.

c. Synthesizing of knowledge: the teacher constructed spatial thinking skill and geography skill during the learning process and throughout projects. Students collected the map projection and geographic analysis present through synchronous online presentations. Reflection was given at the end of the activity to find out the extent to which students achieve meaningful learning.

\section{Test Assessment Techniques}

The test assessment techniques were used the formative assessment and summative assessment. The indicators for spatial thinking skill were referred to the Taxonomy of Spatial Thinking (Jo \& Bednarz, 2009) and the geography skill indicators referred to Geography for Life: National Geography Standard (Sarah W. Bednarz \& Bednarz, 1994). Meanwhile, the indicators of student motivation in the STEM approach were referred to the SMQ (Science Motivation Questionnaire) (Glynn et al., 2011) and the interest indicator referred to the TAT (Teacher's Attitudes Toward Information Technology Questionnaire) (Zaichkowsky, 1985).

\section{Statistic test}

\section{Test Instrument}

The instruments have passed the testing phase in previous studies. This research test was carried out in two stages, the validity test and the reliability test. The result of instrument validation for spatial thinking ability was $>0.5494$, and geography skill was $>0.4973$. Therefore, it is stated valid. The assessment instrument was also validated by expert opinions on learning material, Prof. Budianto and Dr. Budi Handoyo, from the Geography major, State University of Malang.

The reliability test was carried out to explain the level of trust and consistency to reduce errors in the measurement. Based on the calculation of reliability using IBM SPSS Statistics 24 , the tested instrument was indicated valid of $>0.3$. The reliability test of spatial thinking ability was 0.761 , and geographic skill was of 0.850 , then indicated as a high level of reliability $>0.6$.

\section{Data Analysis}

The data analysis was used the normality test, homogeneity test and hypothesis test (independent t-test and Paired t-test). The normality test used the Kolmogorov-Smirnov 
method with the result of spatial thinking ability of 0.200 and geography skill of 0.200 . Then it concluded that the data were normally distributed on two variables.

Homogeneity test uses Levine's test with a significance level of 5\% and a confidence level of $95 \%$. The results of the spatial thinking homogeneity test were found at 0.773 , and geographic skill at 0.577 . Both of these variables showed a significance value > 0.05 , so it was concluded that the data was homogeneous.

Hypothesis testing the ability of spatial thinking and geographic thinking using t-test. Independent t-test was used to find out the different treatment of the two groups to answer research question 1 (RQ 1). Meanwhile, paired t-test used to find out the difference of the mean values in pairs with the normal distribution of data to answer research question 2 (RQ 2). The results of the independent t-test and the mean values of spatial thinking ability indicators were shown in the following tables 2 and 3.

Table 2

Independent T-test and mean of each indicator spatial thinking ability of the post-test score

\begin{tabular}{llll}
\hline \multirow{2}{*}{ Indicator } & Mean & \multirow{2}{*}{ Sig. } \\
\cline { 2 - 4 } & Control group & Experimental group & \\
\hline Concepts of space & 73 & 87 & 0.000 \\
\hline Using Tools of Representation & 72 & 83 & 0.028 \\
\hline Processes of Reasoning & 72 & 83 & 0.008 \\
\hline
\end{tabular}

Table 3

Independent t-test and mean values of geography skill in the post-test

\begin{tabular}{llll}
\hline \multirow{2}{*}{ Indicator } & Mean & \multirow{2}{*}{ Sig. } \\
\cline { 2 - 4 } & Control group & Experimental group & \\
\hline Ask Geographic Questions & 76 & 86 & 0.002 \\
\hline Acquire Geographic Information & 77 & 87 & 0.019 \\
\hline Organize Geographic Information & 76 & 84 & 0.053 \\
\hline Analyze Geographic Information & 75 & 84 & 0.000 \\
\hline Answer Geographic Questions & 75 & 80 & 0.001 \\
\hline
\end{tabular}

\section{FINDINGS}

\section{Research Findings on Problem Question 1}

Answering the first research question (RQ 1), a hypothesis test is needed to see whether $\mathrm{H}^{0}$ is accepted or rejected. The difference in the mean values of the experimental and control groups in the post-test scores was analyzed using an independent sample t-test. The results showed in the following table 4 and table 5 .

Table 4

The mean and standard deviation of the experimental and control groups for spatial thinking skill in post-test

\begin{tabular}{llll}
\hline Grup & $\mathrm{N}$ & Mean & Std. Deviation \\
\hline Experimental & 36 & 85,8 & 6.461 \\
\hline Control & 36 & 73,1 & 7.221 \\
\hline
\end{tabular}


Based on table 4, students who were taught using Blended Project-Based Learning with the STEM approach have the mean values of the experimental group was higher than the control group. Meanwhile, table 5 presented the mean values of the experimental group was higher than the control group on geography skill.

Table 5

The mean and standard deviation of the experimental and control groups for geography skill in post-test

\begin{tabular}{llll}
\hline Grup & $\mathrm{N}$ & Mean & Std. Deviation \\
\hline Exprerimental & 36 & 83,3 & 6.493 \\
\hline Control & 36 & 76,3 & 7.317 \\
\hline
\end{tabular}

Based on table 5, the p-value of the hypothesis test was $0.000<0.05$, so it has a significant difference. This data illustrated that there are differences in the spatial thinking abilities of the two groups. Blended Project-Based Learning model learning with the STEM approach can have a positive influence on the spatial thinking ability of high school students. For this reason, the conclusion hypothesis $\left(\mathrm{H}^{0}\right)$ is rejected.

Table 6

Independent sample t-test results of spatial ability in post-test.

\begin{tabular}{|c|c|c|c|c|c|c|}
\hline & \multirow{2}{*}{$\begin{array}{l}\text { Levene's test for } \\
\text { equality of } \\
\text { variances } \\
\text { F }\end{array}$} & \multirow{2}{*}{ Sig. } & \multicolumn{4}{|c|}{ t-test for Equality of Means } \\
\hline & & & $\mathrm{t}$ & df & $\begin{array}{l}\text { Sig. (2- } \\
\text { tailed) }\end{array}$ & $\begin{array}{l}\text { Mean } \\
\text { difference }\end{array}$ \\
\hline Equal variaces assumed & .119 & .731 & 7.844 & 70 & .000 & 12.667 \\
\hline \multicolumn{2}{|c|}{ Equal variaces not assumed } & & 7.844 & 69.151 & .000 & 12.667 \\
\hline
\end{tabular}

The application of the Blended Project-Based Learning model with the STEM approach also had a positive influence on the geography skill of the experimental group in the population dynamics for Indonesian Development Planning. Table 5, showed the pvalue was $0.000<0.05$, so the difference is significant or hypotheses $\left(\mathrm{H}^{0}\right)$ is rejected.

Table 7

The independent sample t-test results of geography skill in post-test.

\begin{tabular}{|c|c|c|c|c|c|c|}
\hline & \multirow{2}{*}{$\begin{array}{l}\text { Levene's test } \\
\text { for equality of } \\
\text { variances } \\
\text { F }\end{array}$} & \multirow{2}{*}{ Sig. } & \multicolumn{4}{|c|}{ t-test for Equality of Means } \\
\hline & & & & df & $\begin{array}{l}\text { Sig. (2- } \\
\text { tailed) }\end{array}$ & $\begin{array}{l}\text { Mean } \\
\text { difference }\end{array}$ \\
\hline Equal variaces assumed & .314 & .577 & 4.611 & 70 & .000 & 7.500 \\
\hline Equal variaces not assun & & & 4.611 & 68.843 & .000 & 7.500 \\
\hline
\end{tabular}

\section{Research Findings on Problem Question II}

The second research question (RQ2) studied how students' attitudes of the experimental group in learning Geography. The research question can be seen in the following table 8 . 
Table 8

The paired t-test results on spatial thinking abilities and geographic skills

\begin{tabular}{lllll}
\hline & $\mathrm{N}$ & Correlation & Sig. \\
\hline Pair 1 & $\begin{array}{l}\text { Pre-test dan post-test of spasial thinking } \\
\text { skill in the experimental group }\end{array}$ & 36 & .468 & .004 \\
\hline Pair 2 & $\begin{array}{l}\text { Pre-test dan post-test of geography skill in } \\
\text { the experimental group }\end{array}$ & 36 & .508 & .002 \\
\hline
\end{tabular}

Based on table 8, it showed that the attitudes of students taught using Blended ProjectBased Learning with the STEM approach for spatial thinking ability variables has correlation values of 0.468 with a significance of 0.004 and geographic skill has correlation value of 0.508 with a significance of 0.002 . The significance value is smaller than the probability value of 0.05 . It was concluded that there was a relationship between students' attitudes on these two variables.

Based on table 9, it showed about the paired t-test score of the attitude in the experimental group, also the spatial thinking ability and geography skill. The calculation was related to the comparison of the significant value with the probability value and the comparison between the value of $\mathrm{t}$-count with $\mathrm{t}$-table in both variables.

Table 9

The paired t-test results of experimental groups for spatial thinking skills and geography skills

\begin{tabular}{llllllll}
\hline & Mean & $\begin{array}{l}\text { Std. } \\
\text { Deviation }\end{array}$ & $\begin{array}{l}\text { Std. Error } \\
\text { Mean }\end{array}$ & $\mathrm{t}$ & df & .Sig \\
\hline Pair 1 & $\begin{array}{l}\text { Pre-test dan post-test of spasial } \\
\text { thinking skill in the experimental } \\
\text { group }\end{array}$ & -1.39 & 7.07 & 1.17 & -13.49 & 35 & .000 \\
\hline Pair 2 & $\begin{array}{l}\text { Pre-test dan post-test of } \\
\text { geography skill in the } \\
\text { experimental group }\end{array}$ & -1.59 & 6.88 & 1.14 & -12.17 & 35 & .000 \\
\hline
\end{tabular}

Table 9 showed the mean values of -1.39 and -1.59 was different between the pre-test and post-test results on both variables.

Furthermore, table 9 also showed the comparisons between the t-count and t-table on the two variables in the attitude of the experimental group on the two variables. The comparison of t-count and t-table showed values of -12.17 and $-13.49>2.03$. It was obtained through the calculation of the significance value $(\alpha / 2)=0.025$ with $n-1=35$. Therefore, $\mathrm{H}^{0}$ is rejected, and $\mathrm{Ha}$ is accepted.

\section{DISCUSSION}

The learning model is an important element in the learning process. Strengthening concepts in learning adapting easily through the application of learning models (Huili Chen et al., 2020). The BPjBL becomes a new model in the learning process. The 
$\mathrm{BPjBL}$ is a combination of two learning models, emphasizing flexible (synchronous and asynchronous) and project-based learning processes (Bruggeman et al., 2019; LópezPellisa et al., 2020). Instructional design of learning that combining with technology (Huandong Chen et al., 2020), and assisted by structured projects helps students construct cognitive abilities. The BPjBL has various advantages in the learning process. In general, the BPjBL model with a flexible instructional design makes it easier for teachers and students to determine the learning process, both place and time (Wahyudi, 2020). In addition, the BPjBL helps students strengthen concepts through structured projects that are multidisciplinary (Khandakar et al., 2020). Thus, BPjBL has a positive impact on the learning process.

\section{The Blended Project-Based Learning with the STEM Approach to Spatial Thinking Abilities and Geography Skills}

The learning process using Blended Project-Based Learning with the STEM Approach has positive influences on students' spatial thinking skill and geographic skill, compared to the conventional learning applied to the control group. It is supported by previous research that students' learning experiences with the Blended Project-Based Learning model were highly effective, so they need to be implemented consistently (Kokotsaki et al., 2016). Integrating technology is very helpful to facilitate student learning. There would be various development of student competencies if they taught with this model (Sophonhiranrak et al., 2015).

The use of Blended Project-Based Learning has a significant influence on students' knowledge and competencies. Blended Project-Based Learning is learning that teaches and provides learning experiences to answer challenges in the 21 st century (Bell, 2010). These learning experiences encourage the development of conceptual and technical knowledge and professional skill as well as to motivate, help and make a comfortable environment, also to cope with the large numbers of students that cannot be served well (Crawley et al., 2014; Meikleham \& Hugo, 2020).

The results of the first research question (RQ 1) stated that there is the effect of the application of the Blended Project-Based Learning model with the STEM approach to spatial thinking skill and geography skill. The use of Blended Project-Based Learning model with STEM approach was effective to improve students' spatial thinking skill and geography skill. Table 3 showed that the study had a significant effect on the p-value or sig of $0.000<0.05$.

Spatial thinking skill and geography skill can be improved by applying Blended ProjectBased Learning model with STEM approach. Students' spatial thinking ability can be improved through learning finding (inquiry) and exploration (seeking of information) (Kolvoord et al., 2011). Students were also given a stimulus of fundamental questions to find out the spatial framework. Blended Project-Based Learning model with STEM approach also was able to improve students' geography skill through various project activities in the learning process (Chiu et al., 2013). The project activities include calculating and analyzing the population projections in the maps that been presented. 
The STEM approach can effectively assist students to construct spatial thinking processes and geographical skill. The concept of STEM in spatial thinking is viewed from the standpoint of science and technology aspects, including organizing spatial structures, making spatial changes, and describing spatial conclusions (Wakabayashi \& Ishikawa, 2011). The technical aspects of STEM can be identified by focusing on the elements of students' spatial thinking and the elements of spatial representation (Uttal \& Cohen, 2012). There are also mathematical aspects to improve spatial thinking and geography skill with measurement-oriented as a spatial process that includes area and distance (Kolvoord et al., 2011).

Independent t-test on spatial thinking skill statistically showed significant results. Significance values in the indicator of concepts of space, using tools of representation, and processes of reasoning has significance values $<0.05$. Interpretation of the results can be seen in the relevance of Blended Project-Based Learning stages and indicators of spatial thinking ability. Many indicators of spatial thinking processes were achieved in the initial stages of Blended Project-Based Learning. It is because in the initial stages of Blended Project-Based Learning was emphasizes the management of students' cognitive abilities in the learning process.

The acquisition of spatial concepts in depth is constructed through appropriate instructional designs to assist students to learn concepts about a particular subject or subject. In the indicator of concept of space, Blended Project-Based Learning facilitated student to learn through the stages of seeking information and essential questions. Stage of seeking information helped to create active and independent learning activities through the exploration of knowledge and skill (Niemi, 2002; Sivan et al., 2000). Then the stage of essential questions emphasized the deepening of the concept by providing stimulus to students' cognitive and spatial reasoning processes (Epstein et al., 2017).

The spatial ability of students increased through the stages of Blended Project-Based Learning with the STEM Approach. Indicators can be achieved through the exploration of information independently and the stages of design planning on a project-based basis. Through this stage, students are constructed with spatial knowledge by directly applying the spatial reference information that has been obtained in the independent exploration process (Goodchild \& Janelle, 2010; Ishikawa \& Montello, 2006). Such conditions appear in the indicator of processes of reasoning.

There are significant results from Blended Project-Based Learning with the STEM approach to the indicator of processes of reasoning. The emphasis on student cognition management has a significant effect to shape students' processes of reasoning at an early stage. The process of finding information required students to explore and understand concepts in depth (Akyol \& Garrison, 2011). The search formed the processes of reasoning in students' spatial ability. The development of reinforcement, such as basic concepts, information discovery, and synthesizing new knowledge, indirectly formed the processes of reasoning in students' spatial ability (Yeh, 2012).

Significant results also showed in the independent t-test of geography skill. From five indicators, there is one indicator that has almost close to significant value, which is the 
organize geographic information. The indicator could not achieve because of the direct control of teachers to form student skills. Providing various directives at the stage of acqusiting of information with an online system will be very different from direct information. The process of delivering information will depend on the media (Mohammad Yazdi, 2012; Sharma, 2011). Therefore, the significance value on the indicator of acqusiting of information is almost close to significant (0.053).

The stage of synthesizing of knowledge through the stage of asses the outcome and evaluate the experiences have significantly influenced the geography skill variable. The stage helped students to analyze and answer geography questions (Sarah Witham Bednarz et al., 2013). Obtaining new information at the stage of seeking of information affects the indicator of analyze geographic information and answer geographic questions. The stage of synthesizing of knowledge can help students to implement acquired skill and be able to synthesize old knowledge (Kneale, 2014). Next, the stage of evaluate the experiences is conducted based on orientation of geography skill with the indicators of analyze geographic information and answer geographic questions. This stage influenced the application of spatial thinking ability to geography skill (Lee \& Bednarz, 2012; Metoyer \& Bednarz, 2017). The Blended Project Based Learning model with STEM approach showed the learning achievement related to the process of students to find, manage, and use acquired skill, special spatial abilities and geography skill.

\section{Students' Attitudes on implementing Blended Project-Based Learning with STEM Approach in Spatial Thinking Abilities and Geography Skills}

The second research question (RQ 2) was related to students' attitudes in the experimental group while applying the Blended Project-Based Learning model with the STEM approach to spatial thinking and geography skill. The data collection was through a questionnaire in the experimental class before applied the Blended Project-Based Learning model with the STEM approach for about 7 weeks (including pre-application and post-application). The results of these activities were measured using independent ttest to find out the pre-test and post-test scores on students' attitudes while applying the Blended Project-Based Learning model with the STEM approach.

Table 5 and 6 showed statistical data about students' attitudes while applying of the Blended Project Based Learning model with the STEM approach. The results indicated that there are differences in students' attitudes to the two research variables, both spatial thinking variables and geography skill. The results concluded that there are differences in student attitudes while applying the model to the variables, both spatial thinking and geography skill.

Tables 7 and 8 showed the significance of different attitudes in the experimental class. The results were shown through the comparison of $\mathrm{t}$-count and t-table and the comparison of the significance value (sig. 2 tailed) and the probability value (0.05). It also mean that $\mathrm{Ho}$ is rejected and $\mathrm{Ha}$ is accepted (there is a significant difference). The scores represented that there are significant differences in students' attitudes while applying Blended Project-Based Learning models with STEM approaches, both in 
spatial thinking skill and geographic skill. The integrating of project-based learning model with an appropriate and comprehensive approach would be able to assist students to bring up problem-solving attitudes in real contexts (Kaldi et al., 2011; Tseng et al., 2013; Wurdinger et al., 2007).

The results of the study indicated the students' attitudes while applying the Blended Project-Based Learning model with the STEM approach to Spatial Thinking Abilities and Geographic Skill. The attitude in this study includes the motivation and interest to apply Blended Project-Based Learning models with the STEM approach. The significant score in the SMQ attitude indicators can be seen in science and technology through intrinsic motivation, self-efficacy, self-determination, levels of motivation, and motivation in careers (Glynn et al., 2011; Kassaee \& Rowell, 2016). Also, the significant score was seen in students' attitudes regarding the position of the STEM field in learning (Zaichkowsky, 1985).

\section{CONCLUSION}

Blended Project-Based Learning model with STEM approach is effective to be applied in the learning process of Geography. Geography, as part of science subjects, needs to be updated with relevant learning models to achieve optimal learning goals. One of the competencies in geography is spatial thinking ability and geography skill. The results showed that there was an influence of Blended Project-Based Learning model with STEM approach to spatial thinking ability and geography skill. Science, technology, engineering, and mathematics also give influence to students in learning Geography. The results indicated that there are positive changes regarding students' attitudes in learning geography while applying the Blended Project-Based Learning model with the STEM approach. Integration of various fields in the learning process raises different attitudes in students to understand certain subjects. This research showed that a good learning process is constructed through the relevance of the learning materials, students and clear instructional design, so it creates optimal educational interactions in the learning process.

Thus, we can recommend that the use of $\mathrm{BPjBl}$ in Geography learning to improve Spatial Thinking Ability and Geographic Skills to get good quality graduate outcomes of geography. Suggestion, BPJbl to improve Spatial Thinking Ability and Geographic Skill needs to be applied for a long time, continuously and consistently in order to get maximum results.

\section{REFERENCES}

Akyol, Z., \& Garrison, D. R. (2011). Understanding cognitive presence in an online and blended community of inquiry: Assessing outcomes and processes for deep approaches to learning. British Journal of Educational Technology, 42(2), 233-250. https://doi.org/10.1111/j.1467-8535.2009.01029.x

Aliman, M., Budijanto, Sumarmi, Astina, I. K., Putri, R. E., \& Arif, M. (2019). The effect of earthcomm learning model and spatial thinking ability on geography learning outcomes. Journal of Baltic Science Education, 18(3), 323. 
https://doi.org/10.33225/jbse/19.18.323

Anđelković, S., Dedjanski, V., \& Pejic, B. (2018). Pedagogical benefits of fieldwork of the students at the Faculty of Geography in the light of the Bologna Process. Journal of Geography in Higher Education. https://doi.org/10.1080/03098265.2017.1379058

Anggraini, F. I., \& Huzaifah, S. (2017). Implementasi STEM dalam pembelajaran IPA di Sekolah Menengah Pertama. Program Studi Pendidikan Biologi Fakultas Keguruan Dan Ilmu Pendidikan Universitas Sriwijaya, 1(1), 722-731.

Anisimova, T. I., Sabirova, F. M., \& Shatunova, O. V. (2020). Formation of design and research competencies in future teachers in the framework of STEAM education. International Journal of Emerging Technologies in Learning, 15(2), 204-217. https://doi.org/10.3991/ijet.v15i02.11537

Aubusson, P., Schuck, S., \& Burden, K. (2009). Mobile learning for teacher professional learning: benefits, obstacles and issues. ALT-J, 17(3), 233-247. https://doi.org/10.1080/09687760903247641

Bednarz, R. S. (2006). Environmental research and education in US geography. In Journal of Geography in Higher Education (pp. 237-250). https://doi.org/10.1080/03098260600717315

Bednarz, Sarah W., \& Bednarz, R. S. (1994). The standards are coming! Journal of Geography, 93(4), 194-196. https://doi.org/10.1080/00221349408979718

Bednarz, Sarah Witham, Heffron, S., \& Huynh, N. T. (2013). a Road Map for 21st Century Geography Education. In (A report from the Geography Education Research Committee of the Road Map for 21 st Century Geography Education Project) (Vol. 36).

Bell, S. (2010). Project-Based Learning for the 21st Century: Skills for the Future. The Clearing House: A Journal of Educational Strategies, Issues and Ideas, 83(2), 39-43. https://doi.org/10.1080/00098650903505415

Bruggeman, B., Tondeur, J., Pynoo, B., \& Struyven, K. (2019). Experts' insights about blended learning implementation: What teacher attributes are relevant? Proceedings of the European Conference on E-Learning, ECEL, 639-XI. https://doi.org/10.34190/EEL.19.050

Carver, S., Evans, A., \& Kingston, R. (2004). Developing and testing an online tool for teaching GIS concepts applied to spatial decision-making. Journal of Geography in Higher Education, 28(3), 425-438. https://doi.org/10.1080/0309826042000286983

Chang, C. S., Liu, E. Z. F., Sung, H. Y., Lin, C. H., Chen, N. S., \& Cheng, S. S. (2014). Effects of online college student's Internet self-efficacy on learning motivation and performance. Innovations in Education and Teaching International, 51(4), 366-377. https://doi.org/10.1080/14703297.2013.771429

Chen, Huandong, Wu, S., \& Shi, J. (2020). Design of Online and Offline Blending Teaching Mode. In 2020 IEEE 2nd International Conference on Computer Science and 
Educational Informatization

https://doi.org/10.1109/csei50228.2020.9142519

(CSEI),

$268-271$.

Chen, Huili, Park, H. W., \& Breazeal, C. (2020). Teaching and learning with children: Impact of reciprocal peer learning with a social robot on children's learning and emotive $\begin{array}{lllll}\text { engagement. Computers and } & & 103836 .\end{array}$ https://doi.org/10.1016/j.compedu.2020.103836

Chen, R. J. (2010). Investigating models for preservice teachers' use of technology to support student-centered learning. Computers and Education, 55(1), 32-42. https://doi.org/10.1016/j.compedu.2009.11.015

Cheng, K. H., \& Tsai, C. C. (2013). Affordances of Augmented Reality in Science Learning: Suggestions for Future Research. Journal of Science Education and Technology, 22(4), 449-462. https://doi.org/10.1007/s10956-012-9405-9

Chiu, J. L., Malcolm, P. T., Hecht, D., Dejaegher, C. J., Pan, E. A., Bradley, M., \& Burghardt, M. D. (2013). WISEngineering: Supporting precollege engineering design and mathematical understanding. Computers and Education, 67, 142-155. https://doi.org/10.1016/j.compedu.2013.03.009

Clark, J. E. (2010). The Digital Imperative: Making the Case for a 21st-Century Pedagogy. Computers and Composition, 27(1), 27-35. https://doi.org/10.1016/j.compcom.2009.12.004

Claro, M., Preiss, D. D., San Martín, E., Jara, I., Hinostroza, J. E., Valenzuela, S., Cortes, F., \& Nussbaum, M. (2012). Assessment of 21st century ICT skills in Chile: Test design and results from high school level students. Computers and Education, 59(3), 1042-1053. https://doi.org/10.1016/j.compedu.2012.04.004

Crawley, E. F., Malmqvist, J., Östlund, S., Brodeur, D. R., Edström, K., Crawley, E. F., Malmqvist, J., Östlund, S., Brodeur, D. R., \& Edström, K. (2014). Design-Implement Experiences and Engineering Workspaces. In Rethinking Engineering Education. https://doi.org/10.1007/978-3-319-05561-9_5

Cui, P., \& Zheng, L. (2018). A Meta-analysis of the Peer Evaluation Effects on Learning Achievements in Blended Learning Environment. In International Conference on Blended Learning, 227-237. https://doi.org/10.1007/978-3-319-94505-7_18

Daher, W., \& Shahbari, J. A. (2020). Design of STEM activities: Experiences and perceptions of prospective secondary school teachers. International Journal of Emerging Technologies in Learning. https://doi.org/10.3991/ijet.v15i04.11689

de Miguel González, R., \& de Lázaro Torres, M. L. (2018). Spain: Geography Education for Global Understanding. Geography Education for Global Understanding, 183-192. https://doi.org/10.1007/978-3-319-77216-5_15

Duke, B. A., \& Kerski, J. (2010). Geo-Cool: Exploring with Geotechnologies. Learning \& Leading with Technology, 38(2), 28. 
English, M. C., \& Kitsantas, A. (2013). Supporting Student Self-Regulated Learning in Problem- and Project-Based Learning. Interdisciplinary Journal of Problem-Based Learning, 7(2), 128-150. https://doi.org/10.7771/1541-5015.1339

Epstein, R. A., Patai, E. Z., Julian, J. B., \& Spiers, H. J. (2017). The cognitive map in humans: Spatial navigation and beyond. Nature Neuroscience, 20(11), 1504-1513. https://doi.org/10.1038/nn.4656

Erdogan, N., Navruz, B., Younes, R., \& Capraro, R. M. (2016). Viewing how STEM project-based learning influences students' science achievement through the implementation lens: A latent growth modeling. Eurasia Journal of Mathematics, Science and Technology Education, 12(8), 2139-2154. https://doi.org/10.12973/eurasia.2016.1294a

Glynn, S. M., Brickman, P., Armstrong, N., \& Taasoobshirazi, G. (2011). Science motivation questionnaire II: Validation with science majors and nonscience majors. Journal of Research in Science Teaching, 48(10), 1159-1176. https://doi.org/10.1002/tea.20442

Goodchild, M. F., \& Janelle, D. G. (2010). Toward critical spatial thinking in the social sciences and humanities. GeoJournal, 75(1), 3-13. https://doi.org/10.1007/s10708-0109340-3

Gormally, C., Brickman, P., \& Lut, M. (2012). Developing a test of scientific literacy skills (TOSLS): Measuring undergraduates' evaluation of scientific information and arguments. CBE Life Sciences Education, 11(4), 364-377. https://doi.org/10.1187/cbe.12-03-0026

Grant, M. M. (2011). Learning, Beliefs, and Products: Students' Perspectives with Project-based Learning. Interdisciplinary Journal of Problem-Based Learning, 5(2), 37-69. https://doi.org/10.7771/1541-5015.1254

Harris, J., Mishra, P., \& Koehler, M. (2009). Teachers' technological pedagogical content knowledge and learning activity types: Curriculum-based technology integration refrained. Journal of Research on Technology in Education, 41(4), 393-416. https://doi.org/10.1080/15391523.2009.10782536

Hill, A. D., \& Solent, M. N. (1999). Geography on the web: Changing the learning paradigm? Journal of Geography, 98(3), 100-107. https://doi.org/10.1080/00221349908978868

Ishikawa, T., \& Montello, D. R. (2006). Spatial knowledge acquisition from direct experience in the environment: Individual differences in the development of metric knowledge and the integration of separately learned places. Cognitive Psychology, 52(2), 93-129. https://doi.org/10.1016/j.cogpsych.2005.08.003

Jo, I., \& Bednarz, S. W. (2009). Evaluating geography textbook questions from a spatial perspective: Using concepts of space, tools of representation, and cognitive processes to evaluate spatiality. Journal of Geography, 108(1), 4-13. 
https://doi.org/10.1080/00221340902758401

Kaldi, S., Filippatou, D., \& Govaris, C. (2011). Project-based learning in primary schools: Effects on pupils' learning and attitudes. Education 3-13, 3(13), 35-47. https://doi.org/10.1080/03004270903179538

Karakoyun, F., \& Lindberg, O. J. (2020). Preservice teachers' views about the twentyfirst century skills: A qualitative survey study in Turkey and Sweden. Education and Information Technologies, 25, 2351-2369. https://doi.org/10.1007/s10639-020-10148$\mathrm{W}$

Karanikolas, D. N. (2009). Understanding Place: GIS and Mapping across the Curriculum. Cartographic Perspectives, 63, 71-73. https://doi.org/10.14714/cp63.162

Kassaee, A. M., \& Rowell, G. H. (2016). Motivationally-informed interventions for atrisk STEM students. Journal of STEM Education: Innovations and Research, 17(3).

Khandakar, A., Chowdhury, M. E. H., Gonzales, A. S. P., Touati, F., Emadi, N. Al, \& Ayari, M. A. (2020). Case study to analyze the impact of multi-course project-based learning approach on education for sustainable development. Sustainability (Switzerland), 12(2), 480. https://doi.org/10.3390/su12020480

Klein, H. J., Noe, R. A., \& Wang, C. (2006). Motivation to learn and course outcomes: The impact of delivery mode, learning goal orientation, and perceived barriers and enablers. Personnel Psychology, 59(3), 665-702. https://doi.org/10.1111/j.17446570.2006.00050.x

Kneale, P. E. (2014). Study Skills for Geography Students: a Practical Guide 2nd Edition. In Routledge. Routledge.

Kneale, P. E. (2019). Study Skills for Geography Earth and Environmental Science Students. In Routledge. https://doi.org/10.4324/9780203772928

Kokotsaki, D., Menzies, V., \& Wiggins, A. (2016). Project-based learning: A review of the literature. Improving Schools, 19(3), 267-277. https://doi.org/10.1177/1365480216659733

Kolvoord, R. A., Uttal, D. H., \& Meadow, N. G. (2011). Using video case studies to assess the impact of the use of GIS on secondary students' spatial thinking skills. Procedia - Social and Behavioral Sciences, 21, 372-379. https://doi.org/10.1016/j.sbspro.2011.07.039

Krapp, A. (1999). Interest, motivation and learning: An educational-psychological perspective. European Journal of Psychology of Education, 14(1), 23-40. https://doi.org/10.1007/BF03173109

Larson, D. K., \& Sung, C. H. (2009). Comparing student performance: Online versus blended versus face-to-face. Journal of Asynchronous Learning Network, 13(1), 31-42. https://doi.org/10.24059/olj.v13i1.1675

Laurillard, D. (2007). Modelling benefits-oriented costs for technology enhanced 
learning. Higher Education, 54(1), 21-39. https://doi.org/10.1007/s10734-006-9044-2

Laurillard, D. (2009). The pedagogical challenges to collaborative technologies. International Journal of Computer-Supported Collaborative Learning, 4(1), 5-20. https://doi.org/10.1007/s11412-008-9056-2

Law, K. M. Y., Geng, S., \& Li, T. (2019). Student enrollment, motivation and learning performance in a blended learning environment: The mediating effects of social, teaching, and cognitive presence. Computers and Education, 136, 1-12. https://doi.org/10.1016/j.compedu.2019.02.021

Lay, J. G., Chi, Y. L., Hsieh, Y. S., \& Chen, Y. W. (2013). What influences geography teachers' usage of geographic information systems? A structural equation analysis. $\begin{array}{llll}\text { Computers } \text { Education, 62, 191-195. } & \text { 6nd }\end{array}$ https://doi.org/10.1016/j.compedu.2012.10.014

Lee, J., \& Bednarz, R. (2012). Components of Spatial Thinking: Evidence from a Spatial Thinking Ability Test. Journal of Geography, 111(1), 15-26. https://doi.org/10.1080/00221341.2011.583262

López-Pellisa, T., Rotger, N., \& Rodríguez-Gallego, F. (2020). Collaborative writing at work: Peer feedback in a blended learning environment. Education and Information Technologies, 1-18. https://doi.org/10.1007/s10639-020-10312-2

Meikleham, A., \& Hugo, R. (2020). Understanding informal feedback to improve online course design. European Journal of Engineering Education, 45(1), 4-21. https://doi.org/10.1080/03043797.2018.1563051

Metoyer, S., \& Bednarz, R. (2017). Spatial Thinking Assists Geographic Thinking: Evidence from a Study Exploring the Effects of Geospatial Technology. Journal of Geography, 116(1), 20-33. https://doi.org/10.1080/00221341.2016.1175495

Mishra, P., \& Koehler, M. J. (2006). Technological pedagogical content knowledge: A framework for teacher knowledge. Teachers College Record, 108(6), 1017-1054. https://doi.org/10.1111/j.1467-9620.2006.00684.x

Mitchell, P., \& Forer, P. (2010). Blended learning: The perceptions of first-year geography students. Journal of Geography in Higher Education, 34(1), 77-89. https://doi.org/10.1080/03098260902982484

Mohammad Yazdi. (2012). E-learning sebagai Media Pembelajaran Interaktif Berbasis teknologi Informasi. Jurnal Ilmua Foristek, 2(1).

Nellis, M. D. (1994). Technology in geographic education: Reflections and future directions. Journal of Geography, 93(1), 36-39. https://doi.org/10.1080/00221349408979683

Niemi, H. (2002). Active learning - A cultural change needed in teacher education and schools. Teaching and Teacher Education, 18(7), 763-780. https://doi.org/10.1016/S0742-051X(02)00042-2 
Oludare Jethro, O., Moradeke Grace, A., \& Kolawole Thomas, A. (2012). E-Learning and Its Effects on Teaching and Learning in a Global Age. International Journal of Academic Research in Business and Social Sciences, 2(1), 2222-6990.

Owston, R., York, D., \& Murtha, S. (2013). Student perceptions and achievement in a university blended learning strategic initiative. Internet and Higher Education, 18, 3846. https://doi.org/10.1016/j.iheduc.2012.12.003

Ridha, S., Utaya, S., Bachri, S., \& Handoyo, B. (2019). Students' geographic skills in indonesia: Evaluating gis learning material questions using taxonomy of spatial thinking. Journal of Social Studies Education Research, 10(4), 266-287.

Schade, R. E., Al-Enazi, M., Mesbah, S., Anwar, A., Al-hanbali, N., Al-kharouf, R., Alzoubi, M. B., Al-Rasheed, K., I. El-Gamily, H., Bednarz, S. W., Bodzin, A. M., Kolvoord, B., Baker, T. R., Moore, S., Battersby, S., Sinton, D., Uttal, D., Z. Bukhari, Rodzi A.M., ... UN Statistics Division. (2013). A Research Agenda for Geospatial Technologies and Learning. Journal of Geography, 114(3), 118-130. https://doi.org/10.9734/jsrr/2016/22128

Sharma, K. (2011). The Role of ICT in Higher Education for the 21st Century : ICT as A Change Agent for Education. VSRD International Journal of Computer Science \& Information Technology, 1(1), 30-41.

Sivan, A., Wong Leung, R., Woon, C. C., \& Kember, D. (2000). An implementation of active learning and its effect on the quality of student learning. Innovations in Education and Teaching International, 381-389. https://doi.org/10.1080/135580000750052991

Sophonhiranrak, S., Suwannatthachote, P., \& Ngudgratoke, S. (2015). Factors Affecting Creative Problem Solving in the Blended Learning Environment: A Review of the Literature. Procedia - Social and Behavioral Sciences, 174, 2130-2136. https://doi.org/10.1016/j.sbspro.2015.02.012

Sulisworo, D., \& Toifur, M. (2016). The role of mobile learning on the learning environment shifting at high school in Indonesia. International Journal of Mobile Learning and Organisation, 10(3), 159-170. https://doi.org/10.1504/IJMLO.2016.077864

Sun, Z., Xie, K., \& Anderman, L. H. (2018). The role of self-regulated learning in students' success in flipped undergraduate math courses. Internet and Higher Education, 36, 41-53. https://doi.org/10.1016/j.iheduc.2017.09.003

Taylor, H. A., \& Hutton, A. (2013). Think3d!: Training spatial thinking fundamental to stem education. Cognition and Instruction, 31(4), 434-455. https://doi.org/10.1080/07370008.2013.828727

Thomas-Brown, K. A. (2011). Teaching for Geographic Literacy: Our Afterschool Geography Club. The Social Studies, 102(5), 181-189. https://doi.org/10.1080/00377996.2010.509373 
Tseng, K. H., Chang, C. C., Lou, S. J., \& Chen, W. P. (2013). Attitudes towards science, technology, engineering and mathematics (STEM) in a project-based learning (PjBL) environment. International Journal of Technology and Design Education, 23(1), 87102. https://doi.org/10.1007/s10798-011-9160-x

Uttal, D. H., \& Cohen, C. A. (2012). Spatial Thinking and STEM Education. When, Why, and How? In Psychology of Learning and Motivation - Advances in Research and Theory (Vol. 57, pp. 147-181). https://doi.org/10.1016/B978-0-12-394293-7.00004-2

Vesikivi, P., Lakkala, M., Holvikivi, J., \& Muukkonen, H. (2020). The impact of project-based learning curriculum on first-year retention, study experiences, and knowledge work competence. Research Papers in Education, 35(1), 64-81. https://doi.org/10.1080/02671522.2019.1677755

Wahyudi, W. (2020). The effectiveness of sharing blended project based learning (SBPBL) model implementation in operating system course. International Journal of Emerging Technologies in Learning, 15(05), 202-211. https://doi.org/10.3991/IJET.V15I05.11266

Wakabayashi, Y., \& Ishikawa, T. (2011). Spatial thinking in geographic information science: A review of past studies and prospects for the future. Procedia - Social and Behavioral Sciences, 304-313. https://doi.org/10.1016/j.sbspro.2011.07.031

Wilhelm, J. (2014). Research and Teaching: Project-Based Instruction With Future STEM Educators: An Interdisciplinary Approach. Journal of College Science Teaching, 43(4), 80-90. https://doi.org/10.2505/4/jcst14_043_04_80

Wurdinger, S., Haar, J., Hugg, R., \& Bezon, J. (2007). A qualitative study using projectbased learning in a mainstream middle school. Improving Schools, 10(2), 150-161. https://doi.org/10.1177/1365480207078048

Yeh, Y. C. (2012). A co-creation blended KM model for cultivating critical-thinking skills. Computers and Education, 59(4), 1317-1327. https://doi.org/10.1016/j.compedu.2012.05.017

Zaichkowsky, J. L. (1985). Measuring the Involvement Construct. Journal of Consumer Research, 12(3), 341-352. https://doi.org/10.1086/208520

Zydney, J. M., Warner, Z., \& Angelone, L. (2020). Learning through experience: Using design based research to redesign protocols for blended synchronous learning $\begin{array}{lllll}\text { environments. Computers and Education, 143, } 103678 . & .\end{array}$ https://doi.org/10.1016/j.compedu.2019.103678 